\title{
PEMANFAATAN BERITA POLITIK PADA SIARAN TELEVISI SEBAGAI MEDIA PEMBELAJARAN PPKn (DI MTs. NURUSSALAM TETEBATU KECAMATAN SIKUR KABUPATEN LOMBOK TIMUR)
}

\author{
Harianti Hunaeni $^{1}$, Hariyanto $^{2}$, Rispawati $^{3}$ \\ ${ }^{1}$ Mahasiswa prodi PPKn, ${ }^{2}$ Dosen Jurusan Pendidikan IPS \\ Fakultas Keguruan dan Ilmu Pendidikan Universitas Mataram \\ Email: hariyantopkn@gmail.com
}

\begin{abstract}
ABSTRAK
Tujuan penelitian ini adalah untuk mengetahui siaran televisi berita politik apa saja yang dimanfaatkan guru PPKn sebagai media pembelajaran PPKn, cara pemanfaatan berita politik sebagai media pembelajaran PPKn, dan manfaat berita politik sebagai proses pembelajaran PPKn. Penelitian ini menggunakan pendekatan kualitatif dengan metode deskriptif. Teknik pengumpulan data dalam penelitian ini adalah dengan wawancara, observasi dan dokumentasi. Berdasarkan hasil penelitian terungkap bahwa berita politik yang digunakan sebagai media pembelajaran PPKn adalah berita politik tentang Polisi Membentuk Patrol Dunia Maya Untuk Mencegah Kasus Persekusi, Pembangunan Infrastruktur Indonesia, WNI Malaysia Antusias Mengikuti Pemungutan Suara Pada Pemilu 2019, Dan Semangat Toleransi Umat Beragama Di Lingkungan Masjid Istiqlal Dan Gereja Katedral. Bentuk pemanfaatan berita politik yang dijalankan siswa dengan cara kelompok. Semua siswa menonton tayangan televisi yang dijadikan media pembelajaran PPKn. Setelah menonton, masing-masing kelompok mendiskusikan tentang apa yang telah ditonton. Manfaat dari berita politik terhadap pembelajaran PPKn diantaranya dapat menambah pengetahuan politik siswa, dapat membedakan masalah-masalah politik dengan masalah lainnya, dan dapat mengetahui masalah-masalah politik yang terjadi pada saat sekarang, serta mampu meningkatkan kualitas berfikir siswa.
\end{abstract}

Kata Kunci: Berita, Politik, Televisi, dan Media Pembelajaran

\section{ABSTRACT}

The purpose of this study was to determine what political news television broadcasts were used by PPKn teachers as PPKn learning media, how to use political news as PPKn learning media, and the benefits of political news as PPKn learning processes. This research uses a qualitative approach with descriptive methods. Data collection techniques in this study were by interview, observation and documentation. Based on the results of the study it was revealed that the political news used as a learning media for PPKn was political news about the Police Forming a Maya World Patrol to Prevent Persecution Cases, Indonesian Infrastructure Development, Malaysian Citizens Enthusiastic in Participating in the 2019 Election, and the Spirit of Religious Tolerance in the Istiqlal Mosque Environment And the Cathedral Church. Form of utilization of political news that is run by students in a group way. So all students watch television shows that are used as PPKn learning media. After watching, each group discusses what has been watched. The benefits of political news on PPKn learning include being able to increase students 'political knowledge, being able to distinguish political problems from other problems, and being able to find out political problems that are happening at the moment, and being able to improve the quality of students' thinking.

Keywords: News, Politics, Television, Learning Media 


\section{PENDAHULUAN}

Dalam proses belajar mengajar kehadiran media mempunyai arti yang cukup tinggi. Karena dalam kegiatan tersebut ketidakjelasan bahan yang disampaikan dapat dibantu dengan menghadirkan media sebagai perantara. Kerumitan bahan yang akan disampaiakn kepada peserta didik dapat disederhanakan dengan bantuan media. Media dapat mewakili apa yang kurang mampu guru ucapkan melalui kata-kata atau kalimat tertentu. Bahkan keabstrakan bahan dapat dikongkritkan dengan kehadiran media.

Media pembelajaran sangat beragam mulai dilihat dari jenisnya, dari gaya liputnya, dan dari bahan pembuatannya. Salah satunya media berita politik pada televisi termasuk ke dalam media pembelajaranyang dilhat dari gaya liputnya. Televisi merupakan audiovisual, karena memiliki unsur suara dan gambar. Berita politik adalah berita yang soalnya atau masalahnya yang diangkat tentang politik. Berita politik merupakan salah satu komponen pengajaran yang memegang peranan penting dalam proses penyampaian pesan materi, sehingga dapat membantu siswa dalam memahami materi pelajaran. Berita politik di sini adalah berupa informasi yang disiarkan oleh televisi.

Berdasarkan realita di lapangan, pembelajaran PPKn lebih kepada pembelajaran teoritis saja. Pada saat proses pembelajaran jarang sekali teori tersebut dikaitkan dengan kehidupan sehari-hari, itu artinya dalam proses pembelajaran yang dilakukan hanya meningkatkan pengetahuan siswa. Beragamnya media pembelajaran yang dapat dimanfaatkan pada saat ini. Proses pembelajaran tidak hanya terbatas pada peningkatan pengetahuan saja, tetapi harus dapat meningkatkan sikap dan keterampilan siswa. Maka, media pembelajaran menjadi salah satu syarat yang harus dikuasai oleh guru. Berita politik dapat dimanfaatkan sebagai media pembelajaran bagi guru khususnya pada mata pelajaran PPKn. Karena berita politik dapat berpengaruh bagi proses pembelajaran guna meningkatkan pengetahuan, sikap, maupun keterampilan siswa. Jadi, pemanfaatan berita politik sebagai media ini sangat sesuai dengan tujuan pembelajaran PPKn yang telah dirumuskan.

Tujuan dari pembelajaran PPKn adalah untuk meningkatkan kemampuan berfikir kritis siswa serta mencerdasakan siswa, oleh karena itu konsep pembelajaran kontekstual yang ditawarkan sangatlah selaras dengan tujuan pendidikan yang ingin dicapai. Konsep pembelajaran kontekstual berusaha memberikan sesuatu yang bukan abstrak melainkan sesuatu yang nyata sesuai dengan lingkungan sekitar anak, sehingga pengetahuan yang diperoleh anak dengan proses belajar mengajar di kelas merupakan pengetahuan yang dibangun dan dimiliki sendiri. Pembelajaran kontekstual merupakan konsep belajar yang membantu guru mengkaitkan antara materi yang diajarkannya dengan situasi dunia nyata dan mendorong siswa membuat hubungan antara materi yang diajarkannya dengan penerapannya dalam kehidupan mereka sebagai anggota keluarga dan masyarakat.

Berdasarkan hasil paparan di atas peneliti tertarik untuk membahasnya dalam sebuah karya tulis (skripsi), maka peneliti melakukan penelitian tentang hal tersebut dengan mengambil judul "Pemanfaatan berita politikpada siaran televisi sebagai media pembelajaran PPKn di MTs. Nurussalam Tetebatu, Kec. Sikur Kab.Lombok Timur". Karena peneliti merasa bahwa penelitian ini sangat menarik untuk diteliti dalam hal memanfaatkan berita politik pada siaran televisi sebagai media pembelajaran khususnya pada mata pelajaran PPKn, serta meningkatkan pemahaman kritis siswa tentang politik.

\section{METODE PENELITIAN}

Penelitian ini menggunakan pendekatan kualitatif dengan metode deskriptif. Metode deskriptif yaitu penelitian yang dilakukan untuk mencari tahu bagaimana pemanfaatan berita politik pada siaran televisi sebagai media pembelajaran PPKn. Sementara itu, tempat penelitian ini dilaksanakan di MTs. Nurussalam 
Tetebatu yang terletak di jl. Pariwisata Baru No. 05 Dusun Lekong Pituk, Desa Tetebatu Selatan. Adapun mengenai waktu yang dibutuhkan untuk mengumpulkan data tidak dapat dipastikan karena bergantung pada jenis dan jumlah data yang dibutuhkan oleh peneliti. Subjek penelitian dalam penelitian ini adalah guru PPKn di MTs. Nurussalam Tetebatu dan informan adalah siswa yang kelasnya menggunakan berita politik sebagai media pembelajaran. Penelitian ini memperoleh data menggunakan teknik pengumpulan data observasi, wawancara, dan dokumentasi. Keseluruhan data kemudian dianalisis menggunakan teknik reduksi data, penyajian data, dan penarikan kesimpulan serta validitas data.

\section{HASIL DAN PEMBAHASAN}

\section{HASIL}

Pada bagian ini akan dipaparkan hasil wawancara, observasi dan dokumentasi dengan narasumber yang menjadi sumber pada penelitian ini. Proses wawancara dilakukan dengan cara tatap muka langsung dengan para narasumber yang menjadi sumber informasi dari penelitian ini.Untuk waktu dan tempat wawancara disesuaikan dengan keadaan narasumber tersebut kapan dan dimana peneliti dapat melakukan wawancara. Adapun pada penelitian ini peneliti menanyakan dan mengumpulkan informasi tentang garis besar permasalahan dari penelitian, yaitu pertama, siaran televisi berita politik apa saja yang dimanfaatkan guru sebagai media pembelajaran PPKn; kedua, bagaimana cara pemanfaatan berita politik sebagai media pembelajaran PPKn; dan ketiga, bagaimana manfaat berita politik sebagai proses pembelajaran PPKn. Adapun yang menjadi narasumber dalam pelaksanaan wawancara kali ini adalah: satu orang guru PPKn yang mengajar di kelas IX sebagai subjek dan 5 orang siswa kelas IX yang menjadi informan dalam penelitian ini.

Berikut adalah hasil wawancara, observasi dan dokumentasi di MTs. Nurussalam Tetebatu.

\section{Berita Politik yang Dimanfaatkan oleh Guru PPKn Sebagai Media Pembela-jaran PPKn}

Berdasarkan pendapat SF selaku guru PPKn, tidak semua berita politik dapat dijadikan sebagai media pembelajaran PPKn, karena harus disesuaikan dengan materi yang akan diajarkan. Berita politik hampir disetiap stasiun televisi disiarkan. Hanya saja berbeda nama program beritanya. Tapi lebih tepat yang dijadikan sebagai sumber pembelajaran PPKn adalah stasiun televisi seperti TV ONE, METROTV dan KOMPASTV, karena ketiga stasiun televisi tersebut banyak menyiarkan berita-berita termasuk berita politik.

Menurut SF, berita yang pernah dijadikan sebagai sumber belajar PPKn adalah berita politik yang disiarkan pada stasiun televisi yang sudah disebutkan. Berita politik yang digunakan seperti Polisi Membentu Patroli Dunia Maya Untuk Mencegah Kasus Persekusi; 2) Pembangunan Infrastruktur Indonesia; 3) WNI Malaysia Antusias Mengikuti Pencoblosan Pada Pemilu 2019; 4) Semangat Toleransi Umat Beragama Di Lingkungan Masjid Istiqlal dan Gereja Katedral.Berita politik tersebut digunakan sebagai media pembelajaran PPKn karena ada materi pembelajaran yang berkaitan dengan berita.Jadi program atau siaran televisi yang tepat untuk dijadikansumber media pembelajaran PKn adalah yang sesuai dengan materi yang akan diajarkan. Hal tersebut juga di tegaskan oleh HW, bahwa berita politik yang digunakan sebagai media pembelajaran adalah berita politik yang berkaitan dengan materi yang akan dibahas.

Hasil observasi menunjukkan bahwa bahwa berita politik yang digunakan oleh guru PPKn sebagai media pembelajaran adalah berita politik dari stasiun-stasiun televisi yang banyak mengabarkan berita politik, dan berita politik yang digunakan juga harus sesuai dengan materi pembelajaran yang akan diajarkan. Hal ini sesuai dengan hasil observasi dan dokumentasi berupa RPP yang sudah disusun dan berita politik yang guru PPKn gunakan.RPP yang sudah disusun sebelumnya sudah disesuaikan dengan KI dan KD yang sesuai dengan media yang sesuai seperti penggunaan berita politik. Hasil dokumentasi berupa: RPP yang digunakan oleh guru PPKn, Silabus, video berita politik yang sudah digunakan, dan dokumentasi gambar proses pembelajaran guru dan siswa di kelas. 


\section{Cara Pemanfaatan Berita Politik Sebagai Media Pembelajaran PPKn}

Menurut SF, dalam pemanfaatan berita politik sebagai media pembelajaran harus dilakukan perencanaan terlebih dahulu agar dalam proses belajar mengajar berjalan lancar. Perencanaannya yaitu dengan membuat rencana perangkat pembelajaran terlebih dahulu dan menyesuaikan berita politik dengan materi yang akan diajarkan. Menurut SF, bentuk pemanfaatan berita politik yang dijalankan siswa dengan cara kelompok. Semua siswa menonton tayangan televisi yang dijadikan media pembelajaran PPKn. Setelah menonton, siswa dibagi kelompok dan masing-masing kelompok mendiskusikan tentang apa yang telah ditonton. Pendekatan yang digunakan dalam pemanfaatan berita politik sebagai media pembelajaran adalah mengunakan pendekatan kontekstual. SF tidak selalu menggunakan media dalam pembelajaran karena harus disesuaikan dengan materi yang akan diajarkan dan sesuai dengan media yang disediakan di sekolah.

Semua para informan siswa berpendapat senang apabila pada saat proses belajar mengajar menggunakan media. Tetapi sayangnya tidak semua guru menggunakan media pembelajaran.Menurut NA dan responden siswa yang lainnya, setelah menonton siaran televisi yang dijadikan media pembelajaran PPKn selanjutnya bentuk pemanfaatan berita politik dilakukan dengan cara demonstrasi dan diskusi kelompok.

Hasil observasi menunjukan bahwa di dalam kelas pada saat jam pelajaran PPKn pada hari senin tanggal 30 September 2019. Siswa secara berkelompok dalam mencari pokok-pokok pikiran pembukaan UUD-NKRI Tahun 1945. Sebelumnya siswa juga sudah menyaksikan tayangan berita yang berkaitan dengan materi tersebut di dalam kelas yang sudah disiapkan oleh bapak SF selaku guru PPKn. Adapun hasil dokumentasi dari hasil wawancara dan observasi tersebut. Hasil dokumentasi tersebut berupa: RPP, Silabus, Video Berita Politik yang digunakan, dan dokumentasi Proses pembelajaran di kelas.

\section{Manfaat Berita Politik Sebagai Proses Pembelajaran PPKn}

Menurut SF, pemanfaatan program atau siaran televisi berita politik sebagai media pembelajaran PPKn dapat meningkatkan motivasi dan minat belajar, sehingga siswa menjadi antusias dalam belajar. Menurut SF, banyak manfaatnya dari berita politik terhadap pembelajaran PPKn diantaranya informasi yang disajikan akan lebih mudah dipahami siswa, memudahkan siswa menyerap informasi yang disampaikan guru, pembelajaran akan lebih menarik perhatian siswa karena dengan adanya berita politik ini materi akan lebih jelas maknanya bagi siswa, membangkitkan aktifitas tanya jawab, dapat menambah pengetahuan politik siswa, siswa dapat membedakan masalah-masalah politik dengan masalah lainnya, dan siswa dapat mengetahui masalah-masalah politik yang terjadi pada saat sekarang. Sehingga dapat dikatakan berita politik adalah sebagai media atau alat untuk memacu atau merangsang rasa ingin tahu siswa terhadap politik yang terjadi di dalam kehiduan sekarang ini. Sementara itu menurut NA dan para informan lainnya, dengan memanfaatkan berita politik sebagai media pembelajaran dapat meningkatkan kualitas berfikir, lebih mudah memahami pelajaran yang disampaikan guru dan dengan menonton berita politik pada siaran televisi dapat mengetahui tentang masalah-masalah politik.

Hasil observasi menunjukkan bahwa siswa menjadi lebih aktif di dalam kelas untuk bertanya, lebih berani dalam menyampaikan hasil temuan mereka di kelas, dapat membedakan berita politik sesuai dengan materi yang sedang dipelajari dan sebagainya. Hal tersebut sesuai dengan apa yang diamati langsung oleh peneliti pada saat proses pembelajaran sedang berlangsung di dalam kelas pada tanggal 30 Sep, tanggal 3 dan 7 Okt 2019.

\section{PEMBAHASAN}

\section{Siaran Televisi Berita Politik yang dimanfaatkan Guru PPKn sebagai Media Pembelajaran PPKn}

Berdasarkan hasil penelitian menunjukan bahwa berita pada siaran televisi yang digunakan oleh guru PPKn di MTs. Nurussalam Tetebatu sebagai media pembelajaran adalah berita politik, karena politik 
berkaitan dengan penyelenggaraan Negara dan pemerintahan. Hal ini sesuai dengan pernyataan menurut Karim Suryadi yang dikutif dalam skripsi Kurnia (2010: 20) mendefinisikan bahwa berita politik adalah berita yang mengandung unsur politik dan laporan bermakna mengenai peristiwa politik. Adapun yang dimaksud dengan unsure berita politik tersebut harus mengandung unsure $5 \mathrm{~W}+1 \mathrm{H}$, sedangkan peristiwa politik yang dimaksud sesuai dengan pandangan Surbakti (Efriza, 2008:23) bahwa politik adalah:

1. Politik adalah usaha-usaha yang ditempuh warga negara untuk membicarakan dan mewujudkan kebaikan bersama.

2. Politik adalah segala hal yang berkaitan dengan penyelenggaraan negara dan pemerintahan.

3. Politik adalah sebagai segala kegiatan yang diarahkan untuk mencari dan mempertahankan kekuasaan dalam masyarakat.

4. Politik sebagai kegiatan yang berkaitan dengan perumusan dan pelaksanaan kebijakan umum.

5. Politik sebagai konflik dalam rangka mencari dan atau mempertahankan sumber-sumber yang dianggap penting.

KD yang cocok menggunakan berita politik sebagai media pembelajaran PPKn adalah KD.3.2 tentang Pokok-Pokok Pikiran Dalam Pembukaan UUD-NRI Tahun 1945. Pada KD tersebut terdapat beberapa sub indikator yang cocok dalam memanfaatkan berita politik sebagai media pembelajaran. Seperti pembahasan pokok pikiran pertama berkaitan dengan social budaya, berita politik yang digunakan seperti Polisi Membentuk Patroli Dunia Maya Cegah Kasus Persekusi. Pembahasan pokok pikiran kedua berkaitan dengan perekonomian, berita politik yang digunakan seperti pembangunan inprastruktur Indonesia. Pembahasan pokok pikiran ketiga berkaitan dengan Pemilu, berita politik yang digunakan adalah WNI Malaisya antusias mengikuti pemungutan suara. Pembahasan pokok pikiran ke empat berkaitan dengan SARA, berita politik yang digunakan adalah Semangat Tolerasi Umat Beragama di Lingkungan Masjid Istiqlal dan Gereja Katedral.

Adapun berita politik yang sering digunakan sebagai media pembelajaran oleh guru PPKn di MTs. Nurussalam Tetebatu adalah berita politik tentang pemilu. Berita yang digunakan seperti WNI Malaisya antusias mengikuti pencoblosan pada pemilihan Capres dan Cawapres Tahun 2019 di TPS KBR Kuala Lumpur. Tercatat ada 558.000 orang lebih yang mengikuti pemilihan tersebut. Alasan penggunaan berita tersebut sebagai media pembelajaran PPKn pada materi pokok pikiran ketiga adalah untuk melihat sejauhmana kedaulatan rakyat sesuai dengan UUD 1945 dijalankan dengan semestinya. Hal ini sesuai dengan unsur-unsur berita menurut Romli (2014: 6) dimana mengandung 5W+1H.

Saat proses pembelajaran berlangsung, berita politik yang digunakan sebagai media ini berperan untuk mencari tahu bagaimana sinkronnya materi pembelajaran dengan realita dalam kehidupan sehari-hari. Seperti pada pokok pikiran ketiga UUD-NRI tahun 1945 yaitu: "Negara yang berkedaulatan rakyat, berdasarkan atas kerakyatan dan permusyawaratan/perwakilan.” Jadi dengan menggunakan berita politik tentang pemilu tersebut, siswa dapat mengetahui sejauhmana kedaulatan berada ditangan rakyat.Apakah sudah sesuai dengan system negara yang terbentu dalam Undang-Undang Dasar atau tidak.

Dengan demikian, antara keduanya terjadi saling mengisi. Sehingga program/ siaran televisi berita politik yang dimanfaatkan oleh guru PPKn sebagai media pembelajaran PPKn yaitu program atau siaran yang berhubungan dengan materi yang akan diajarkan. Seperti materi tentang Pemilu, maka yang dijadikan sumber berita politiknya mengenai pemilu. Sehingga tidak semua siaran televisi berita politik dapat dijadikan sebagai sumber media pembelajaran PPKn, karena harus disesuaikan dengan materi yang akan diajarkan.

\section{Cara Pemanfaatan Berita Politik sebagai Media Pembelajaran PPKn}

Berdasarkah hasil penelitian dalam memanfaatkan berita politik sebagai media pembelajaran harus dilakukan perencanaan terlebih dahulu agar dalam proses belajar mengajar berjalan lancar. Perencanaannya yaitu dengan membuat rancanagn perangkat pembelajaran terlebih dahulu dengan menyesuaikan berita 
politik dengan materi yang akan diajarkan. Hal ini sesuai yang dikemukakan oleh Bahri dan Zain (2006:136) bahwa ada enam langkah yang bisa ditempuh guru pada waktu mengajar dengan menggunakan media, ialah sebagai berikut:

1. Merumuskan tujuan pembelajaran dengan memanfaatkan media

2. Persiapan guru

3. Persiapan kelas

4. Langkah penyajian pelajaran dan pemanfaatan media

5. Langkah kegiatan belajar siswa

6. Langkah evaluasi pengajaran

Berdasarkan hasil penelitian menunjukan bahwa dalam memanfaatkan berita politik pada siaran televisi yang digunakan oleh guru PPKn di MTs Nurussalam Tetebatu harus dilakukan perencanaan terlebih dahulu. Hal ini dibuktikan dengan hasil observasi terhadap guru PPKn sebagai subjek penelitian yang menyatakan bahwa dalam proses pemanfaatan media tersebut harus dilakukan perencanaan terlebih dahulu yaitu dengan menyusun RPP yang sesuai dengan materi pembelajaran yang akan menggunakan media berita politik tersebut. Dalam hal ini guru harus memperhatikan materi pembelajaran dan berita politik apa yang sesuai dengan kebutuhan pengajaran nantinya.

Bentuk pemanfaatan berita politik yang dijalankan siswa dengan cara demonstrasi dan diskusi kelompok. Jadi semua siswa menonton tayangan televisi yang dijadikan media pembelajaran PPKn. Setelah menonton, siswa dibagi kelompok dan masing-masing kelompok mendiskusikan tentang apa yang telah ditonton. Siswa diajarkan untuk mengaitkan antara materi yang diajarkannya dengan situasi dunia nyata siswa dan mendorong siswa membuat hubungan antara pengetahuan yang dimilikinya dengan penerapannya dalam kehidupan mereka sehari-hari. Hal ini sesuai dengan US Departement of Education, 2001 bahwa pendekatan kontekstual merupakan konsep belajar yang membantu guru mengaitkan antara materi yang diajarkan dengan situasi dunia nyata siswa dan mendorong siswa membuat hubungan antara pengetahuan yang dimilikinya dengan penerapannya dalam kehidupan mereka sebagai anggota keluarga dan masyarakat.

Hal ini sesuai dengan pembelajaran PPKn yang menuntut siswa lebih aktif dalam proses pembelajaran sehingga siswa mampu mengambil peran dan tanggung jawabnya sebagai warga Negara yang baik. Hal ini sesuai dengan pernyataan Kerr (Dahlan, 2015: 31), yang mengemukakan bahwa "PPKn secara luas mencakup proses penyiapan generasi muda untuk mengambil peran dan tanggung jawabnya sebagai warga negara. Pembelajaran Pendidikan Pancasila dan Kewarganegaraan dirancang berbasis aktivitas terkait dengan sejumlah tema kewarganegaraan yang diharapkan dapat mendorong siswa menjadi warga negara yang baik melalui kepeduliannya terhadap permasalahan dan tantangan yang dihadapi masyarakat sekitarnya. Kepedulian tersebut ditunjukkan dalam bentuk partisipasi aktif dalam pengembangan komunitas yang terkait dengan dirinya. Kompetensi yang dihasilkan bukan lagi terbatas pada kajian pengetahuan dan keterampilan penyajian hasil kajiannya dalam bentuk karya tulis, tetapi lebih ditekankan kepada pembentukan sikap dan tindakan nyata yang harus mampu dilakukan oleh tiap siswa. Dengan demikian akan terbentuk sikap yang cinta dan bangga sebagai bangsa Indonesia.

Model pembelajaran dikembangkan sesuai dengan karakteristik PPKn secara holistik/utuh dalam rangka peningkatan kualitas belajar danpembelajaran yang berorientasi pada pe ngembangan karakter peserta didik sebagai warga negara yang cerdas dan baik secara utuh dalam proses pembelajaran otentik (authentic instructional and authenticlearning) dalam bingkai integrasi Komp etensi Inti sikap, pengetahuan, dan keterampilan. Serta model pembelajaran yang mengarahkan peserta didik bersikap dan berpikir ilmiah (scientific) yaitu pembelajaran yang 
mendorong dan menginspirasi peserta didik berpikir secara kritis, analistis, dan tepat dalam mengidentifikasi, memahami, memecahkan masalah, dan mengaplikasikan materi pembelajaran.

Hasil penelitian mengukapkan bahwa bentuk pemanfaatan berita politik yang dijalankan oleh siswa dalam bentuk kelompok. Sebelumnya siswa diberikan tugas terlebih dahulu untuk menonton siaran televisi yang berkaitan dengan materi pembelajaran yang akan dibahas. Setelah itu siswa mentukan pokok-pokok bahasan dari berita politik yang sudah mereka tonton lalu mendiskusiakn kembali hasil temuan mereka lalu dipersentasikan. Dengan demikian siswa sangat senang apabila pada saat proses belajar mengajar menggunakan media. Siswa menjadi lebih aktif dan interaksi antara guru dan siswa terbangun saat proses pembelajaran berlangsung. Pemanfaatan berita politik pada siaran televisi sebagai media pembelajaran PPKn di MTs Nurussalam Tetebatu ini sangat banyak manfaatnya bagi guru maupun siswa.

\section{Manfaat Berita Politik sebagai Proses Pembelajaran PPKn}

Berdasarkan hasil penelitian menunjukan bahwa pemanfaatan media pembelajaran yang diterapkan oleh guru PPKn MTs Nurussalam Tetebatu mampu meningkatkan motivasi belajar dan rangsangan kegiatan belajar. Sesuai dengan yang dikemukakan Hamalik dalam (Arsyad, 2005: 15) bahwa pemakaian media pembelajaran dalam proses belajar mengajar dapat membangkitkan keinginan dan minat yang baru, membangkitkan motivasi dan rangsangan kegiatan belajar, dan bahkan membawa pengaruh-pengaruh psikologis terhadap siswa.

Media pembelajaran adalah suatu alat bantu bagi guru agar proses belajar mengajar lebih menyenangkan dan tidak membosankan serta dapat meningkatkan motivasi belajar. Media pembelajaran yang berbasis teknologi informasi seperti televisi, sangatlah menarik perhatian siswa pada materi pelajaran. Dengan menggunakan berita politik sebagai media pembelajaran PPKn dapat meningkatkan motivasi dan minat belajar, sehingga siswa menjadi antusias dalam belajar. Hal ini sesuai dengan pernyataan Sanjaya, (2011: 169) bahwa manfaat media pembelajaran adalah sebagai berikut :

1. Menangkap suatu objek/ peristiwa-peristiwa tertentu

2. Memanifulasi keadaan, peristiwa, atau objek tertentu

3. Menambah gairah dan motivasi belajar siswa

Ditegaskan lagi dengan pernyataan Sudjana \& Rivai dalam Arsyad (2005: 24-25) mengemukakan manfaat media pembelajaran dalam proses belajar siswa, yaitu:

a. Pembelajaran akan menarik perhatian siswa sehingga dapat menumbuhkan motivasi belajar,

b. Bahan pelajaran akan lebih jelas maknanya

c. Metode mengajar akan lebih bervariasi,

d. Siswa dapat lebih banyak melakukan kegiatan belajar

Hal ini dikarenakan ketika guru menggunakan media tersebut manfaat dari berita politik terhadap pembelajaran PPKn diantaranya dapat menambah pengetahuan politik siswa, siswa dapat membedakan masalah-masalah politik dengan masalah lainnya, dan siswa dapat mengetahui masalah-maslah politik yang terjadi pada saat sekarang. Sehingga dapat dikatakan berita politik adalah sebagai media atau alat untuk memacu atau merangsang rasa ingin tahu siswa terhadap politik yang terjadi di dalam kehidupan sekarang ini, selain itu dapat meningkat kualitas berfikir siswa. 


\section{SIMPULAN}

Berdasarkan hasil penelitian dan pembahasan dapat dirumuskan simpulan bahwa: berita politik yang digunakan sebagai media pembelajaran PPKn adalah berita politik tentang (1) Polisi Membentuk Patrol Dunia Maya Untuk Mencegah Kasus Persekusi, (2) Pembangunan Infrastruktur Indonesia, (3) WNI Malaysia Antusias Mengikuti Pemungutan Suara Pada Pemilu 2019, Dan (4) Semangat Toleransi Umat Beragama Di Lingkungan Masjid Istiqlal Dan Gereja Katedral.

Dalam pemanfaatan berita politik sebagai media pembelajaran harus dilakukan perencanaan terlebih dahulu agar dalam proses pembelajaran bisa terarah dan berjalan lancar. Bentuk pemanfaatan berita politik yang dijalankan oleh siswa adalah dengan cara kelompok. Jadi semua siswa menonton siaran berita politik yang dijadikan sebagai media pembelajaran PPKn. Setelah menonton, siswa dibagi kelompok dan masingmasing kelompok mendiskusikan tentang apa yang telah ditonton.

Dengan menggunakan berita politik sebagai media pembelajaran PPKn dapat meningkatkan motivasi dan minat belajar, sehingga siswa menjadi antusias dalam belajar.Banyak manfaatnya dari berita politik terhadap pembelajaran PPKn diantaranya dapat menambah pengetahuan politik siswa, siswa dapat membedakan masalah-masalah politik dengan masalah lainnya, dan siswa dapat mengetahui masalah-masalah politik yang terjadi pada saat sekarang. Sehingga dengan memanfaatkan siaran televisi berita politik dapat meningkatkan kualitas berfikir siswa.

\section{DAFTAR PUSTAKA}

Bahri, syaiful Djamarah dan Aswan Zain. 2006. Strategi Belajar Mengajar. Jakarta: PT Rineka Cipta Budiardjo, m. 1978.Dasar-Dasar ilmu Politik. Jakarta: PT. Gramedia Pustaka Utama

Budiningsih, Asri. 2005. Belajar dan Pembelajaran. Jakarta: Rineka Cipta.

Dimyati \& Mudjiono. 2006. Belajar dan Pembelajaran. Jakarta: PT Rineka Cipta.

Djamarah, Syaiful Bahri \& Zain Aswan. 2006. Strategi Belajar Mengajar. Jakarta: PT Rineka Cipta. Ismail, M. 2014. Strategi Pembelajaran PPKn. Mataram: Universitas Mataram

Ittihad, Zainal. 2007. Pendidikan Kewarganegaraan. Jakarta: Universitas Terbuka

Moleong, Lexy. 2007. Metodologi Penelitian Kualitatif. Bandung: PT Remaja Rosdakarya.

S. Margono. 1997. Metodologi Penelitian. Jakarta: Rineka Cipta.

Subandi, I. 2007. Kecerdasan Komunikasi Seni Berkomunikasi kepada Publik. Bandung: Refika offset.

Sugiyono, 2007.Metode Penelitian Pendidikan; Pendekatan Kuantitatif, Kualitatif dan R\&D. Mataram: Alfabeta

Uno, Hamzah. 2009. Profesi Kependidikan Problema, solusi, dan reformasi Pendidikan di Indonesia. Jakarta: Bumi Aksara 